4th International Scientific Conference SEC-IASR 2019, Galati, Romania, 7th - 8th June, 2019

\title{
Sociological Considerations on Social Inequalities and Disparity of Opportunities in Education
}

\author{
Gabriela-Violeta IORDĂCHIT, $\breve{A}$ \\ https://doi.org/10.18662/lumproc/sec-iasr2019/18
}

How to cite: Iordăchiță, G.V. (2020). Sociological Considerations on Social Inequalities and Disparity of Opportunities in Education. In S. Marin \& P. Moisescu (vol. eds.), Lumen Proceedings: Vol. 12. 4th International Scientific Conference SEC-LASR 2019 (pp. 160-168). Iasi, Romania: LUMEN Publishing House.

https://doi.org/10.18662/lumproc/sec-iasr2019/18 


\title{
Sociological Considerations on Social Inequalities and Disparity of Opportunities in Education
}

\author{
Gabriela-Violeta IORDĂCHIȚA $\breve{A}^{1}$
}

\begin{abstract}
The studies on inequalities in educational opportunities have been conducted along studies on social mobility, social class stratification and forming or studies concerned with the evolution of modern democracies. Our theoretical approach represents a critical analysis of the education system in order to identify state policies or common practices which do not lead to a better operation of the state itself. Our goal is that of identifying such aspects and introduce them on the public agenda in order to create remedial public policies.

Conclusions show that a decrease of income inequality distribution among social classes and a democratic, merit-based political system which is not subjected to legislation or procedure changes at short times would increase equity and social cohesion of a society, thus creating better work and life opportunities for a larger number of people.
\end{abstract}

Keywords: social inequalities; disparity of opportunities in education; communism; development; merit-based society.

\footnotetext{
${ }^{1}$ Assistant Professor, Ph.D. Candidate., "Dunarea de Jos" University of Galați, Faculty of Medicine and Pharmacy and Faculty of Physical Education and Sport, The Training Department of the Teaching Staff, gabrielaiordachita@gmail.com, +40336-108-917.
} 


\section{Introduction}

In a community, as a common and natural reality of democratic societies, social inequalities among individuals take various forms regarding each individual's advantages and disadvantages within the social area. An accident which impedes on the professional career, a poorer genetic background or a serious congenital defect, a lower or even much higher IQ, inherited wealth or poverty, belonging to a dominant or dominated group, class or age category, or even gender can represent a disparity should the rest of the people team up and react to such conditions.

The concept of social inequity has a very long history. For example, Aristotle, in Politics, identifies in the nature the source of inequities and free people's superiority compared to slaves, men's to women, Greeks' to barbarians. [8] Later, the source of disparities among people was seen to come from property, regardless the liberal or socialist political doctrines are considered, the utilitarian shift preceded by John Locke, Jeremy Bentham or Thomas Hobbes' [3] or Jean Jacques Rousseau's [3] ideas. The last author widely debated on the property 's emergence as cause for disparities among people in the Discourse on the Origin and Basis of Inequality among Men (1754) and The Social Contract (1756), and such ideas have become an ever-living inspiration source for both the Marxist utopia that strongly affected many countries in the world, including Romania, and the $20^{\text {th }}$ century geopolitics.

\section{Theoretical Background}

In sociology of education [19] the questioning of inequalities is one of or even the most important query, although as old as the education itself. On what concerns the researches in education sociology [12], there can be considered that analysis of disparity of opportunities in education went along studies on social mobility, social class segregation and emerging or studies on evolution of modern democracies. Constantly, various models have been proposed. For example, there can be mentioned the causal theories [9], the social and cultural reproduction theories (P. Bourdieu, J. C. Passeron), the theory of educational transmission (B. Bernstein), social labeling theory $(\mathrm{H}$. S. Becker) and the larger group of functionalist (E. Durkheim, T. Parsons), conflict (K. Marx, M. Weber) or constructivist (P. Berger, T. Luckmann) theories. A special place among the theorists is occupied by Raymond Boudon [4], [5], who stressed upon the impact of social origin status as source for inequities in education and society, idea previously uttered by A. C. Anderson [1], according to whom there is no connection between 
mobility in education and social mobility; henceforth an amplifying phenomenon of certificates' depreciation caused by their increased number in the social area

The concept of social inequity is also closely related to that of social stratification. Actually, there is no society without a layering of various social groups or classes according to certain criteria, resulting in a social class overlapping structure as geological layers in the ground. In fact, many thinkers approached the matter over the years. For example, in the $19^{\text {th }}$ century, classics of social thinking in the first stages of modern capitalism evolution were concerned with the social inequity issue. In this regard, there can be mentioned Adam Smith [3], followers of Saint Simon like Auguste Comte [3], Engels and Marx, Alexis Tocqueville [3], Le Play, John Stuart Mill and Gobineau, their concepts thoroughly influencing, in a way or another, their posterity.

The $20^{\text {th }}$ century was no exception for the studying of inequality issues. Some notable examples: Vilfredo Pareto and his theories related to the alleged constancy of income distribution pattern and the circulation of political elites [17], Robert Michaels and his famous "iron law of oligarchy" [16], the works of Pitirim Sorokin on social mobility [17], the study of Lynds (1929, 1937), Middletown [3], the paper Who Shall be Educated? [3] written by Warner, Havighurstand Loeb, (1944), representatives of Chicago School. There also must be mentioned Charles Wright Mills [3], Ralph Dahrendorf [3], Jean Gabriel Tarde [3] and the Finnish mathematician A. Aulin and his law of requisite hierarchy [17] or Pierre Bourdieu [6], [7] who during the '60s developed a pattern concept for analysis of new domination forms based on the cultural and symbolic capital.

The $21^{\text {st }}$ century is greatly hallmarked by Joseph Stiglitz' [16] studies about inequalities and the mechanisms for maintaining and propagating such inequalities in the society or about policies' role in creating and deepening inequalities in the American society together with the important issues concerning the precise methodology for measuring inequalities. In 2001, Stiglitz, with A. Michael Spence and George A. Akerlof, won the Nobel Prize for Economics in 2001 for laying the foundations for the theory of markets with asymmetric information.

Another researchers concerned of inequality issues are Thomas Piketty [13] whose thinking is greatly influenced, in various ranges, by Francoise Simiand's ideas [3], the French historians Ernest Labrousseand Adeline Daumard or Karl Polanyi [14], Pierre Bourdieu [6], [7] and Christian Baudelot. Among them, Piketty [13] considers important the use of previous centuries' data end experience in order to find solutions to avoid continuous 
future growth of social polarization and such is possible only by economic transparency and a democratic control on capitals.

\section{Romania, between social inequity, disparity of opportunities for education and the egalitarian ideology of a communist and totalitarian state}

Social equality is that ,social condition identified by equal treatment of all society members in what concerns their obligations and rights and mostly their equal access to commonly shared resources." [17] Analogical to defining the social equality, equality of opportunities for education is represented by equal access to educational resources, a feature effecting on someone's educational scores and route. Also, equal access to education is a human fundamental right according to the Universal Declaration of Human Rights (1948) and an essential step for each individual's personal evolution, for laborers' specializing in order to grow the local, regional and European cohesion level and overcome the "social borders" [10] to achieve an increasing social mobility. [15]

Before December 1989, the educational system of Romania had been for more than four decades an important vehicle for promoting egalitarianism, but one harmonized to the political ideology of the totalitarian state, causing multiple and thorough changes in the society structure. The said construction represented a social engineering serving the communist régime goals and was founded on the utopian Marxist ideas of the class struggles where "the proletarian becomes a forerunner of history, rushing the world toward communism, that supreme phase when the dissolution of social classes shall unavoidably be accompanied by the dissolution of state". [11]

Thus, during the post World War II era up to the wave of political changes brought by the year of 1989 across the entire Eastern Europe, Romania was the experimentation territory for the Marxist-Leninist ideology for 40 years. Out of an excess of egalitarianism, that ideology prohibited the access to higher education for children coming from wealthy or intelectual families or to those having parents or relatives who had had various leading positions in the previous monarchist régime or even political views considered to be against the communist system. An interesting study from 1993 regarding this matter and conducted shortly after the fall of totalitarian régimes în the Eastern Europe [20] concluded that socialist régimes, besides all efforts, did not succeeded in either establishing a more egalitarian system for educational seggregation or rearranging the social layers for any of the countries the said study has been conducted for: Bulgaria, Czechoslovakia, 
Hungary, Poland or Russia. None the less, the study could not fully exclude the impact of egalitarian policies applied in time. This situation is strongly opposable to that of China where periodic changes of state policies seem to have direct impact on life opportunities for people belonging to various social environments and classes. For example, în the context of more radical and egalitarian educational policies established during the Cultural Revolution, children coming from highly educated and upper classes were noticeably discriminated in what concerns their access to education compared to children coming from middle and lower classes.

It would be desirable for the Romanian society to provide equal access to education for all children and adult people by ensuring free educational services, infrastructure and requisite learning materials. However, the reality of last three decades is defined by insufficient funds for education and an increased school drop-out rate of 18,1\%. In Denmark, $8.7 \%$ of GDP was allocated for education, $7.3 \%$ of GDP in Cyprus and 7\% of GDP in Sweden. According to the National Statistics Institute for 2018, the Romanian Education system was provided funds amounting 3.1\% out of the GDP, increased by 3 billion RON compared to 2017 but much below the needs of the system. Although there has been politically committed a level of $6 \%$ of the GDP for allocation from the state budget to education, the percentage was not complied with and funds invested in the Romanian education never exceeded a threshold of $4 \%$ of the GDP.

Before December 1989, as previously mentioned, the educational system in Romania was an important instrument for promoting egalitarianism and fulfilled a need for specialized personnel required by the country's industry under development and, for such reasons, investments in education were higher. Yearly allocated amounts reached almost $10 \%$ of the GDP in the '80s. During the same period, remarkable steps forward were made especially in widening the school going population and developing the vocational education, but also in enhancing the infrastructure by building new schools and kindergartens. However, limitation of some social classes to high education and exacerbation of enrolling workers' or peasants' children in universities by a positive discrimination towards other children were not always efficient measures from the economic point of view or in what concerns the workforce quality.

It's worth asking the question: considering the effects, to what extent is use of political power justified for interfering with someone's right of access to education, regardless the social origin? The purpose for such policies had a sole justification, that of creating a new social class, accepted by the political régime and meant to support, under the generous and utopian umbrella of egalitarianism, the organization of a totalitarian state. 
After 1989, although the political domination upon the educational system weakened its ideological pressure and intensity, the present times perpetuate reminiscences from the past, especially considering the common and deeply established practice of rotating the managers in education according to the political orientation of various alternating governments. Presently, merit-based appointment of teachers in managerial positions is rather an exception from the rule than a general rule of the system. Such often and rapid changes stress out the educational system's lack of coherence and stability.

\section{Disparity of income and inequalities in access to education}

In table 1, data show consistent differences in evolution for countries formerly under Soviet domination in what concerns the distribution of disparity of income. In the Czech Republic, Slovakia, Hungary and Poland, such inequalities for the two quintiles (S80/S20) are below the yearly European average, while for Bulgaria, Romania, Latvia, Lithuania and Estonia the income distribution inequalities are above the European average. The last are also the countries with a fifth or more of the population exposed to poverty risks according to the same data from Eurostat. At the other end, the lowest percentage of people exposed to poverty risks were in the Czech Republic (9,7\%) in 2015. Thus, two different categories can be distinguished among the nine former communist countries: the first four mentioned countries are more developed and have a better social justice, and the last five countries, with Romania among them, facing higher poverty levels and more disparity of income distribution. Such facts reinforce the concept that a better labor remuneration and more decrease of differences among wages would contribute to a reduction of social inequalities.

Table 1. Distribution of income disparities in the former communist countries [21]

\begin{tabular}{c|cccccccccc}
\hline Year & $\mathbf{2 0 0 8}$ & $\mathbf{2 0 0 9}$ & $\mathbf{2 0 1 0}$ & $\mathbf{2 0 1 1}$ & $\mathbf{2 0 1 2}$ & $\mathbf{2 0 1 3}$ & $\mathbf{2 0 1 4}$ & $\mathbf{2 0 1 5}$ & $\mathbf{2 0 1 6}$ & $\mathbf{2 0 1 7}$ \\
$\begin{array}{c}\text { Country } \\
\text { Bulgaria }\end{array}$ & 6.5 & 5.9 & 5.9 & 6.5 & 6.1 & 6.6 & 6.8 & 7.1 & 7.9 & 8.2 \\
Czech & & & & & & & & & & \\
Republic & 3.4 & 3.5 & 3.5 & 3.5 & 3.5 & 3.4 & 3.5 & 3.5 & 3.5 & 3.4 \\
Estonia & 5.0 & 5.0 & 5.0 & 5.3 & 5.4 & 5.5 & 6.5 & 6.2 & 5.6 & 5.4 \\
Latvia & 7.3 & 7.4 & 6.8 & 6.5 & 6.5 & 6.3 & 6.5 & 6.5 & 6.2 & 6.3
\end{tabular}




\begin{tabular}{ccccccccccc} 
Lithuania & 6.1 & 6.4 & 7.3 & 5.8 & 5.3 & 6.1 & 6.1 & 7.5 & 7.1 & 7.3 \\
Hungary & 3.6 & 3.5 & 3.4 & 3.9 & 4.0 & 4.3 & 4.3 & 4.3 & 4.3 & 4.3 \\
Poland & 5.1 & 5.0 & 5.0 & 5.0 & 4.9 & 4.9 & 4.9 & 4.9 & 4.8 & 4.6 \\
Romania & 7.0 & 6.5 & 6.1 & 6.2 & 6.6 & 6.8 & 7.2 & 8.3 & 7.2 & 6.5 \\
Slovakia & 3.4 & 3.6 & 3.8 & 3.8 & 3.7 & 3.6 & 3.9 & 3.5 & 3.6 & 3.5 \\
Average & & & & & & & & & & \\
in EU & 5.0 & 4.9 & 4.9 & 5.0 & 5.0 & 5.0 & 5.2 & 5.2 & 5.2 & 5.08 \\
\hline
\end{tabular}

At this moment, an issue faced by many countries, even ones with established democracies like the USA, is to be remembered - that of extreme levels of income based social segregation defining a society where outrageous richness lives side by side with misery and poverty. In such conditions, inequality becomes social inequity and education cannot ameliorate such discrepancies but only in isolated cases.

\section{Fighting back the opposite views}

The main opposers to the theory of inequality reduction among social classes are the neo-liberal thinkers, promoters of Polak model [2] used by the IMF. This model proved its inefficiency especially in the Latin America during the '80s. Moreover, the model had disastrous after-effects on long term, such as increase of unemployment rate, decreasing mobility for large masses of people, and finally euthanisation of state as property owner and investor.

\section{Conclusions}

Decreasing the disparity of income distribution among social classes and increase of GDP percentage allocated to education would create the requisite conditions leading to equal opportunities of access to quality long term education and a school-drop rate decrease among children coming from lower or middle classes.

At the same time, establishment of a democratic and stable political system would improve social equity and cohesion, thus emerging better work and life opportunities for a larger number of people. 


\section{References}

[1] Anderson AC. A Skeptical note on the Relation of Vertical Mobility to Education.American Journal of Sociology. Chicago:The University of Chicago Press; 1961. 66(6): 560-570.

[2] Ban C. Dependență și dezvoltare. Economia politică a capitalismului românesc. Cluj-Napoca: Tact Publisher; 2014. 86 p.

[3] Borlandi M. Dictionar al gândirii sociologice. Iași:Polirom; 2009. 885 p.

[4] Boudon R. L’Inégalité des chances.Paris: Armand Colin;1973. 239 p.

[5] [Boudon R. Effects pervers et ordre social,Paris: PUF; 1977. 286 p.

[6] Bourdieu P. Reproduction culturelle et reproduction sociale, SAGE;1971 [cited 2019 Oct 10]; Available from: https://doi.org/10.1177/053901847101000203.

[7] Bourdieu P, Passeron JC. La Reproduction. Éléments pour une théorie dusystème d'enseignement. Paris: Les Editions de Minuit;1970. 283 p.

[8] Cherkaoui M, Stratificarea. In Tratat de sociologie. Boudon R. (ed.); București: Humanitas; 1997. 112 p.

[9] Flude M. Sociological accounts of differential ability. In Flude M., Aheir J. (eds.). Educability, Schools and Ideology. London: Croom Helm; 1974. pp. 1522

[10] Gheorghiu MD, Saint Martin M. Educație şi frontiere sociale. Franța, România, Brazilia, Suedia. Iaşi: Polirom; 2011. 262 p.

[11] Lallement M. Istoria ideilor sociologice. Vol. I De la origini până la Weber.Oradea: Antet; 1997. 239 p.

[12] Marks GN. The Measurement of Socio-economic Inequalities in Education. In Acta Sociologica; 2004. 47(1):91-93.

[13] Piketty T.Capitalul în secolul al XXI-lea. Bucuresti: Litera; 2015. 1008 p.

[14] Polanyi K. Marea transformare. Originile politice și economice ale epocii noastre. Cluj-Napoca: Tact; 2013. 476 p.

[15] Rotariu T. Şcoala şi mobilitatea socială în țările capitaliste dezvoltate: Studiu metodologic.București: The Scientific and Encyclopedic Publishing House; 1980. $259 \mathrm{p}$.

[16] Stiglitz J. Pretul inegalitatii. Cum societatea divizată din ziua de astăzi ne pune in pericol viitorul. Bucuresti: Publica; 2013. 615 p.

[17] Ungureanu I. Paradigme ale cunoaşterii societății. Iași: Junimea; 2002. 278 p.

[18] Zamfir C, Vlăsceanu L (eds.). Dicționar de sociologie. Bucuresti: Babel; 1998. $205 \mathrm{p}$.

[19] Znaniecki F. Obiectul sociologiei educației. In Fred Mahler (ed.). Sociologia educației și învățământului. Antologie de texte contemporane de peste hotare. Bucuresti: The Didactic and Pedagogical Publishing House; 1975. pp. 53-62.

[20] Wong RSK. Egalitarianism versus Social Reproduction:Stratification in Eastern Europe in Baker D., Fuller B., Hannum E., Verum R. Inequality across Societies: Families, Schools and Persisting Stratification. Netherlands: Elsevier; 2004. pp. 139-170. 
Gabriela-Violeta IORDĂCHIȚĂ | Lumen Proceedings 12 | SEC-IASR 2019

[21] Eurostat Data Explorer S80/S20 income quintile share ratio by sex and selected age group-EU-SILC and ECHP surveys. [cited 2019 Oct 14]. Available from: http://appsso.eurostat.ec.europa.eu/nui/show.do?dataset=ilc di11\&lang=en.[ 